\title{
The influence of film type and processing method on radiographic density for occlusal caries diagnosis
}

\author{
- Henrique Auriemo Pellegrini School of Dentistry, University of São Paulo, SP, Brazil • Ana da Silveira Department of \\ Community Dentistry, Federal University of Pará, Belém, PA, Brazil • Cesar Angelo Lascala Department of Stomatology, \\ School of Dentistry, University of São Paulo, SP, Brazil - Claudio Costa Department of Stomatology, School of Dentistry, \\ University of São Paulo, SP, Brazil • Maria Aparecida Alves de Cerqueira Luz Department of Operative Dentistry, School of \\ Dentistry, University of São Paulo, SP, Brazil
}

ABSTRACT | Objective: This study aimed to investigate how the radiographic processing method affect the radiographic density of two types of film. Methods: Radiographs from non-cavitated occlusal caries lesions obtained in a previous study were used. We analyzed 28 films from 12 patients that were obtained with the same X-ray device. Seven Ektaspeed (Kodak Eastman Kodak Co, Rochester, NY, USA) and seven Ultraspeed (Kodak Eastman Kodak Co) films were manually processed, while seven Ektaspeed and seven Ultraspeed films were automatically processed. The angle of incidence of the X-ray beam and the distances between the apparatus, the tooth and the film were standardized. Therefore, the study comprised four groups: GE1: Ektaspeed manually processed; GE2: Ektaspeed automatically processed; GU1: Ultraspeed manually processed; and GU2: Ultraspeed automatically processed. The images were digitized (G40450 Scan Jet C/T, Hewlett-Packard) and analyzed using Digora for Windows 2.7 (Soredex Medical Systems) to obtain the average radiographic density, and data were analyzed using Student's t test for paired data (Bioestat 5.3). Result: Only the Ektaspeed film showed statistically significant differences among radiographic densities with different processing methods ( $\mathrm{p}=$ 0.0037). Conclusion: The Ektaspeed film automatically processed is better suited for the early diagnosis of caries lesions.

DESCRIPTORS | X-Ray Diagnosis; Dental Caries; Digital Dental Radiography; Community Dentistry.

RESUMO | Influência do tipo de filme e método de processamento na densidade radiográfica para diagnóstico de cárie oclusal • Objetivo: Este estudo tem como objetivo estudar a influência do método de processamento na densidade radiográfica de dois tipos de filmes. Métodos: Foram utilizadas radiografias de lesões de cárie oclusais não cavitadas obtidas em estudo prévio. Foram analisados 28 filmes obtidos de 12 pacientes cujas radiografias foram realizadas com o mesmo aparelho radiológico. O mesmo número de filmes (n=7) Ektaspeed (Kodak Eastman Kodak Co, Rochester, NY, USA) e Ultraspeed (Kodak Eastman Kodak Co) foram processados manualmente e automaticamente. Desta forma, o estudo compreendeu quatro grupos: GE1: Ektaspeed processado manualmente $(\mathrm{n}=7)$; $\mathrm{GE} 2$ : Ektaspeed processado automaticamente $(n=7)$; GU1: Ultraspeed processado manualmente $(n=7)$ e GU2: Ultraspeed processado automaticamente $(\mathrm{n}=7)$. As imagens foram digitalizadas (G40450 Scan Jet C/T, Hewlett-Packard) e analisadas utilizando o programa Digora for Windows 2.7 (Soredex Medical Systems) para obter a média da densidade radiográfica. Os dados foram analisados através do teste T de Student para dados pareados (Bioestat 5.3). Resultado: Apenas o filme Ektaspeed mostrou diferenças estatisticamente significantes entre as densidades radiográficas com os diferentes métodos de processamento $(\mathrm{p}=0.0037)$. Conclusão: O filme Ektaspeed processado automaticamente é mais apropriado para o diagnóstico precoce de lesões de cárie oclusal.

DESCRITORES | Diagnóstico Radiográfico; Cárie Dental; Radiografia Dental Digital; Odontologia em Saúde Coletiva.

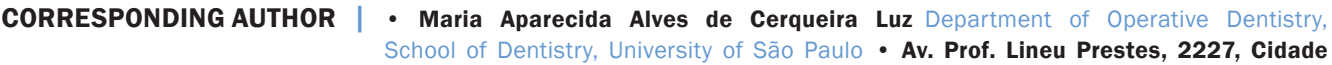
Universitária São Paulo, SP, Brazil • 05508-900 Email: maacluz@usp.br

- Received Sep 02,2015 • Accepted Oct 23, 2015

- Dol http://dx.doi.org/10.11606/issn.2357-8041.clrd.2015.2804 


\section{INTRODUCTION}

The diagnosis of dental caries using imaging has evolved significantly, and a detailed analysis of images using appropriate software facilitates the early diagnosis of dental caries. The use of direct and semi-direct digital systems or conventional radiography (indirect digital radiography) associated with specific software programs provides detailed information that can be used for diagnosis. By using these resources, density and contrast can be changed to improve the interpretation of images. ${ }^{1}$ The use of dedicated software, such as Digora for Windows 2.7, Image Tool, or Vix Win, enables the measurement of degrees of grey in the images, which may be quantified and translated to numerical values of image density. The 8-bit system display a range of 256 degrees of gray on a scale from zero, fully radiolucent, up to fully radiopaque.,

Regardless the method used to evaluate a radiographic exam, many factors contribute to a suitable radiographic image, including exposure time, processing method, angle of incidence of the radiation beam and type of film used..$^{1-5}$

Therefore, this research aims to verify the effect of the processing method, either manual or automatic, with two types of film, Ektaspeed and Ultraspeed, on the radiographic density values of occlusal, non-cavitated caries lesions using Digora for Windows 2.7®.

\section{METHODS AND MATERIALS}

Radiographs were used from non-cavitated occlusal caries lesions obtained in a previous study by Silveira ${ }^{6}$. Twenty-eight radiographs obtained from 12 patients at the same time were analyzed using Spectro II (Dabi Atlante, Ribeirão Preto, SP, Brazil) at $50 \mathrm{kV}, 10 \mathrm{~mA}$, and an exposure time of 0.5 s. Seven Ektaspeed (Kodak Eastman Kodak Co, Rochester, NY, USA) and seven Ultraspeed (Kodak Eastman Kodak Co, Rochester, NY, USA) films were processed manually according to the temperature/time table provided by the manufacturer, while seven Ektaspeed and seven Ultraspeed films were processed in a Peri-Pro III nonroller automatic processing machine (Air Techniques, New York, NY, USA). Radiographs were taken with a standardized angle of incidence of the X-ray beam and at a standardized distance between the appliance and the tooth film, which was determined using an acrylic resin bite guide. ${ }^{6}$ Therefore, the radiographs could be repeated with the same distance from the film source $(40 \mathrm{~cm})$ and the same vertical and horizontal angulations. Two types of radiographic films and the same X-ray device were used for each patient.

This study comprised four groups: GE1: Ektaspeed manually processed; GE2: Ektaspeed automatically processed; GU1: Ultraspeed manually processed; and GU2: Ultraspeed automatically processed.

Radiographs were digitized at a resolution of 75 dpi using a scanner with a transparency reader (ScanJet G40450 C/T, Hewlett-Packard, Palo Alto, CA, USA). The images were stored in JPG format with maximum quality, without image manipulation. The digitized radiographic images were analyzed using Digora for Windows $® 2.7$ (Soredex Medical Systems, Tuusula, Finland) to obtain the average radiographic density. These values were tabulated and analyzed using Student's $t$ test for paired data to determine whether there was a significant difference between groups (Bioestat 5.3).

\section{RESULTS}

Results were obtained by correlating the radiographic density and processing method (automatic or manual) for the two types of films.

Statistical analysis of the digitized radiographs showed a statistically significant difference in radiographic density between processing methods with the Ektaspeed film $(p=0.0037)$. The 
Ultraspeed film showed no statistically significant difference between processing methods. Mean values and confidence intervals for the two types of films are shown in Table 1, and Graphic 1 shows the distribution of the radiographic density values for the four groups.

Table 1 | Mean radiographic density according to the processing method for Ektaspeed and Ultraspeed films using Student's t test (means, standard deviation (SD) and 95\% confidence interval of differences).

\begin{tabular}{c|c|c|c|c|c}
\hline Film & Manual & Automatic & \multicolumn{3}{|c}{ Paired Differences } \\
\hline & Mean $( \pm S D)$ & Mean $( \pm S D)$ & Mean $( \pm S D)$ & $\begin{array}{c}95 \% \text { confidence } \\
\text { interval of differences }\end{array}$ & Lower Upper \\
\hline $\begin{array}{c}\text { Ektaspeed } \\
(n=14)\end{array}$ & $\begin{array}{c}144.35 \\
( \pm 19.91)\end{array}$ & $\begin{array}{c}116 \\
( \pm 19.67)\end{array}$ & $\begin{array}{c}-28.35 \\
( \pm 30.08)\end{array}$ & $-45.72-10.99$ & 0.0037 \\
\hline $\begin{array}{c}\text { Ultraspeed } \\
(n=14)\end{array}$ & $\begin{array}{c}164.42 \\
( \pm 15.71)\end{array}$ & $\begin{array}{c}161.35 \\
( \pm 14.30)\end{array}$ & $\begin{array}{c}3.07 \\
( \pm 22.46)\end{array}$ & -9.89 & 16.04 \\
\hline
\end{tabular}

Note: Paired difference values were obtained by subtracting the initial value from the final value; therefore, negative values indicate an increase in the coefficient after 12 months of follow-up. † Significance level

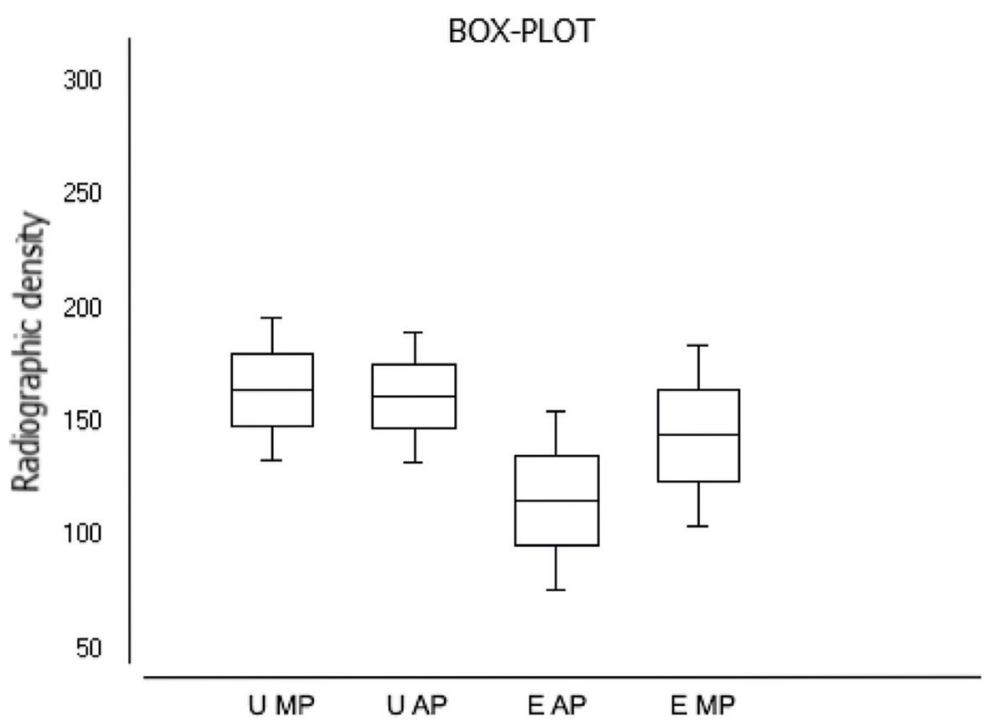

Graphic 1 | Radiographic density of both types of films using manual processing (MP) and automatic processing (AP).

\section{DISCUSSION}

This study originated from the study of Silveira, ${ }^{6}$ which evaluated the effect of different pit and fissure sealing materials in the treatment of non-cavitated occlusal caries lesions. In this study, the radiographs used for the control treatment were obtained in a standardized manner using a positioner customized for each patient. In addition, the X-ray device, film type and processing method were standardized. The current lack of standardization in the chemical processing of radiographs is common in different types of dental care. According to Costa, ${ }^{7}$ professionals do not follow quality control programs. The difficulties in 
obtaining high-quality radiographs are related to a lack of adequate facilities, the use of visual processing methods, incomplete chemical processing, and a lack of knowledge about the characteristics of the processing solutions.?

Generally, the progression of a lesion in dentin causes a partial collapse of the enamel, resulting in color changes and/or translucency of the tissue. On a radiographic examination, these initial tissue changes produce radiolucent images below the amelodentin junction. However, recent studies have reported the possibility of lesion progression in dentin under apparently intact surface enamel that are difficult to detect in grooves and pits using conventional clinical methods; these studies show the necessity of radiographic examinations to help to diagnose these lesions. ${ }^{8-10}$ In addition to aiding in the diagnosis, the radiographic examination can be useful for clinical monitoring and it is the preferred method for progression analysis of these lesions. ${ }^{2,11-15}$

Regarding the quality of radiographic examinations, continuous studies should be performed with different types of film, chemical solutions and processing methods to improve the accuracy of these examinations and, consequently, the diagnosis and/or monitoring of carious lesions in their initial stages of development. Early diagnosis can make conservative and/or minimally invasive treatments possible. Worldwide, $60-90 \%$ of schoolchildren and nearly $100 \%$ of adults have tooth decay. ${ }^{16}$ This fact made this disease a focus of those who practice conservative dentistry and prioritize minimal intervention to maintain the integrity of dental elements over conventional restorative treatments that require a more invasive approach to caries lesions and weaken the dental elements. ${ }^{17}$

According to Lotto, ${ }^{18}$ the use of radiographs in the diagnosis of carious lesions is possible because of differences in radiolucency among tissues. More mineralized tissue appears as a white area or radiopaque on a radiographic examination, while softened tissue appears dark or radiolucent. In a radiographic exam, an injury in dentin below an apparently sound enamel appears as a radiolucent line between the enamel (more radiopaque) and the sound dentin (middle radiolucency). Special care must be taken to avoid misinterpreting this line as the "mach band" effect, i.e., an optical illusion due to the adjacency of a dark area to another light area, giving the impression of an intermediate area between the two that could be confused with dentine lesions. ${ }^{18}$ The film quality and activity of processing solutions are important for obtaining a good-quality image that can assist in the diagnosis and may be assessed using the sensitometric method, which measures characteristic curves of such properties as contrast, sensitivity and latitude.?

Two factors may be responsible for the variation in the results: the latitude and the sensitivity of the films. Sensitivity is the response of a film to electromagnetic radiation (light or X-rays) and is verified after radiographic processing to obtain optical densities. ${ }^{19,20}$ Latitude is the larger or lesser ability of a film to be under-exposed or over-exposed and still produce images of adequate quality for interpretation. ${ }^{19,20}$ Manual and automatic processing resulted in statistically significant differences for Ektaspeed film images, which can affect clinical diagnosis when using this type of film. This film is more sensitive, which can be attributed to its lower processing latitude and may be explained by Graphic 1 , in which there is a visible difference in radiographic density between manual and automatic processing. The Ultraspeed film has increased processing latitude, probably because its radiographic density varies less between different types of processing.

Regarding the use of films in dental clinics, a film with a small latitude would have a greater capacity to show an incipient carious lesion than a film with a greater latitude, which, in turn, would be less sensitive. This is a critical choice in community dental 
health clinics, in which early diagnosis is critical, ${ }^{21}$ but controlling such variables to obtain good radiographic images may be very difficult. However, as we consider that the processing techniques should be controlled as much as possible to obtain optimal image quality, the more suitable film for auxiliary diagnosis exams of incipient dental caries lesions is the E group of sensitivity (Ektaspeed), which also exposes patients to lower radiation doses. In clinical practice, it is important to observe the processing type (manual or automatic) and the type of film used to obtain the best possible image and, consequently, make the correct diagnosis.

\section{CONCLUSION}

E films (Ektaspeed), which are more sensitive, are more suitable for auxiliary diagnosis exams in the early diagnosis of caries lesions, particularly if they are processed automatically for better control of the image quality. However, when practitioners are less experienced and automatic processors are not available, or when undergraduate students are interpreting images, less sensitive films such as the Ultraspeed are indicated.

\section{REFERENCES}

1. Oliveira EF, Carminatti G, Fontanella V, Maltz M. The monitoring of deep caries lesions after incomplete dentine caries removal: results after 14-18 months. Clin Oral Invest. 2006 Jun;10(2):134-9.

2. Léda L, Azevedo TD, Pimentel PA, Toledo AO, Bezerra AC. Dentin Optical Density in Molars Subject to Partial Carious Dentin Removal. J Clin Pediatr Dent. 2015 Fall;39(5):452-7. doi: 10.17796/1053-4628-39.5.452

3. Hashimoto K, Thunthy KH, Weinberg R. Automatic processing: effects of temperature and time change on sensitometric properties of Ultraspeed and Ektaspeed films. Oral Surg Oral Med Oral Pathol Oral Radiol Endod. 1991 Jan;71(1):120-4.

4. Hesse D, Bonifácio CC, Raggio DP, Imparato JCP. Avaliação do selamento de lesões de cárie comparado à restauração com resina composta em dentes decíduos. Stomatos. 2007 Jul-Dec;13(25)75-85.
5. Maltz M, Alves LS, Jardim JJ, Moura MS, Oliveira EF. Incomplete caries removal in deep lesions: a 10 year prospective study. Am J Dent. 2011 Aug;24(4):211-4.

6. Silveira ADS. Efeito de diferentes materiais no selamento de lesões cariosas de sulcos e fóssulas sem cavitação clínica: um ensaio clínico, controlado, randomizado [tese]. São Paulo: Universidade de São Paulo, Faculdade de Odontologia; 2013.

7. Costa C, David AF, David SMN, Matsui RH, Castilho JCM, Varoli FP. Estudo das densidades base e velamento obtidas de filmes radiográficos em diferentes condições de processamento. Ciênc Odontol Bras. 2005 Jan-Mar;8(1):90-6.

8. Creanor SL, Russell JI, Strang DM, Stephen KW, Burchell CK. The prevalence of clinically undetected occlusal dentine caries in Scottish adolescents. Br Dent J. 1990 Sep 8;169(5): 126-9.

9. Ricketts D, Kidd E, Weerheijm K, de Soet H. Hidden caries: what is it? Does it exist? Does it matter? Int Dent J. 1997 Oct;47(5):259-65.

10. Weerheijm KL, Kidd EA, Groen HJ. The effect of fluoridation on the occurrence of hidden caries in clinically sound occlusal surfaces. Caries Res. 1997;31(1):30-4.

11. Espelid I, Tveit AB, Fjelltveit A. Variations among dentists in radiographic detection of occlusal caries. Caries Res. 1994;28(3):169-75.

12. Ekstrand KR, Ricketts DN, Kidd EA. Occlusal caries: pathology, diagnosis and logical management. Dent Update. 2001 Oct;28(8):380-7.

13. Angnes G, Angnes V, Grande RH, Battistella M, Loguercio $\mathrm{AD}$, Reis A. Occlusal caries diagnosis in permanent teeth: an in vitro study. Braz Oral Res. 2005 Oct-Dec;19(4):243-8.

14. Valera FB, Pessan JP, Valera RC, Mondelli J, Percinoto C. Comparison of visual inspection, radiographic examination, laser fluorescence and their combinations on treatment decisions for occlusal surfaces. Am J Dent. 2008 Feb;21(1):25-9.

15. Silveira AD, Borges BC, Almeida Varela H, de Lima KC, Pinheiro IV. Progression of non-cavited lesions in dentin throught a nonsurgical approach: a preliminary 12-month clinical observation. Eur J Dent. 2012 Jan;6(1):34-42.

16. World Health Organization. Oral health - Policy Basis; 2013. [cited 2013 Feb 3]. Avaible from: https://goo.gl/d5TLgK.

17. Bader JD, Shugars DA. The evidence supporting alternative management strategies for early occlusal caries and suspected occlusal dentinal caries. J Evid Based Dent Pract. 2006 Mar;6(1):91-100. 
18. Lotto RB, Williams SM, Purves D. Mach bands as empirically derived associations. Proc Natl Acad Sci U S A. 1999 Apr;96(9):5245-50.

19. Thunthy KH, Weinberg R. Sensitometric comparison of Kodak Ektaspeed Plus, Ektaspeed, and Ultra-speed dental films. Oral Surg Oral Med Oral Pathol Oral Radiol Endod. 1995 Jan;79(1):114-6.
20. Thorogood D, Horner K, Smith NJD. Quality control in the processing of dental radiographs. A pratical guide to sensitometry. Brit Dent J. 1998 May 7;164(9):282-7.

21. Carvalho JC, Mestrinho HD. Diagnosing non-cavitated lesions in epidemiological studies: practical and scientific considerations. Braz Oral Res. 2014;28 Spec No:1-7. doi: 10.1590/ S1806-83242013005000036. 